\title{
Examination of Comedy Through a Television Serial: Case of Çocuklar Duymasın
}

\author{
Özlem Tören, Eastern Mediterrenean University, TRNC \\ Bahire Efe Özad, Eastern Mediterrenean University, TRNC
}

\begin{abstract}
Among the TV genres, sitcoms seek to entertain the audience while raising their awareness on certain issues. One of the most popular Turkish TV serials of all times is Çocuklar Duymasin (Don't Let Children Hear). This serial is produced by Birol Güven and started to be broadcasted in 2002. The serial has been on the air till 2014 on several TV channels. During this time, it was produced for a few years and re-appeared with a new format. The new version was on the air after 2012 till 2014. Pathos mentioned in Aristotelian rhetoric analysis is formed throughout the serial with the sound of laughter. Comedy is formed through jokes and are classified in the serial. For the present study, 60 episodes of Çocuklar Duymasin broadcasted in 2014 are examined and the types of jokes that are followed with the sound of laughter is categorized as simple and intellectuel jokes. The results suggest that number of messages based on simple-everyday life jokes is more than intellectual ones.
\end{abstract}

Keywords: Çocuklar Duymasın, comedy, simple joke, intellectual joke, pathos, rhetoric analysis, content analysis. 


\section{Introduction}

Long ago, Aristotle drew our attention to the fact that rhetoric could be used for persuading people through speech in the pre-literacy era (Rapp, 2010). What he advised then, is still valid. Rhetoric is used for persuading people through both speech and written materials. For Aristotle, in the most general sense, rhetoric is the ability to use the available methods of persuasion in certain situations. He categorized rhetoric under three main categories, ethos, pathos and logos (Freese, 1926).

According to Freese (1926), Aristotle used ethos to articulate the moral character's views, values and manners. Ethos is the power of a personal character in order to make the orator's speech convincing. Thus, the moral character sending the message has to be credible to convince the audience about his/her ideas and arguments. Freese (1926) also states that pathos stimulates emotions of the audience. Pathos appeals to the heart instead of affecting the head because the speaker affects emotions or imaginations of the audience with stories, inspirational quotes and vivid language. In other words, the character or speaker's messages touch the emotions to persuade the audience. Thus, pathos is the power of activation of enthusiasm of the audience. Furthermore, Aristotle defines 'logos' as the proof strength of a truth by convincing evidence. The speaker has logical supportive argument because the message itself has to be logical and well presented. The arguments, facts and evidence should have coherent structure. References should have statistics or case studies which includes comparisons, analogies and methods (Freese, 1926). Berger (2011) contends that rhetorical analysis is used to interpret the works not only in the literature and films but also on radio and television programs because of the development of the mass media. According to Berger (2011, p.88):

"In media and communication research, rhetoric plays an important role because it gives a large number of concepts that enable us to understand how a text generates meaning and helps shape people's emotions and behaviors."

In television serials, rhetorical devices are used within and outside the scenes (Neeley, 2005). For example, Yin and Yun (2012) analyze the effect of rhetorical devices in the dialogues of the American TV series The Big Bang Theory in their study. Their study aims to find out how English sitcoms are influential for learning English. According to Yin and Yun (2012), 
Growing Pains (1985), Friends (1994) and The Big Bang Theory (2007) have become part of English learners' life in China through the portrayals of ordinary people in daily life because all of them help English learners improve their linguistic competence, getting educated while entertained. When the Turkish TV serials or sitcoms are examined, it is observed that there is not a study that considers how rhetoric is constructed in the serial through voice/sound of laughter. For example, the aim of the present study is to show how the voice of laughter has been used in the Çocuklar Duymasın (Don't Led Children Hear) sitcom in order to create 'pathos' for fun.

\section{A Brief Information about Çocuklar Duymasın}

Çocuklar Duymasın is a very popular and well-known sitcom which has been broadcasted since 2002 in Turkey. Thus, the audience loves watching this sitcom which was on the air between 2002 and 2014. Birol Güven who is the producer and scenarist of Çocuklar Duymasin produced this sitcom firstly for the TV channel TGRT in 2002. During this time, 14 episodes of Çocuklar Duymasın was broadcasted in this channel. The serial was on the air for 50 episodes that were produced between Januarry 2002 and May 2002 in Atv. After 2004, the name of the serial changed to "What will happen to children?" This was because of the difficulties caused by the main character: Meltem and Haluk were having in their private lives. Later, the serial started to be broadcasted again August 8, 2004 by Birol Güven. It finished in March 2005 (Özsoy, 2005). Furthermore, Çocuklar Duymasın was produced again in Atv in 2010. Lastly, Fox TV began to produce this sitcom during the period between 2013 and 2014. After the $160^{\text {th }}$ episodes, the serial was ceased to be produced (Facebook.com/Cocuklar Duymasin, 2015).

In this sitcom, the story revolves around the life of a modern Turkish family. In this family there is a working mother and father, a teenager daughter and a young son. The main character is Meltem who is also an ideal mother and the Human Resource Director of the company. She is a modern wife, a good daughter, a trustful friend and a respected neighbor. Meltem has a good communication with people around her and has an ability to solve every problem. Haluk is the father of the family. He is portrayed as a stronger character but he is married to Meltem who is also a strong character. Through the character of Haluk, the scenarist and producer of the sitcom represents a macho Turkish man. Even though Meltem always convinces Haluk through a discussion and her ideas, still he acts in a macho way. The 
daughter of this family is called Duygu. She has grown up and become a lawyer. Duygu's role model is her mother, Meltem. Emre who is the son of the family is a relaxed and energetic university student. Emre's close friend is called Teo. Both of them fall in love with two modern and beautiful sisters who are neighbors of Emre. These girls' names are Melis and Ece. Both of them are university students like Emre and Teo. The neighbor of Meltem and Haluk is called Idil. Idil is a successful and reasonable psychologist. She gives some suggestions to people in order to make them cope with their problems in their lives. For example, Idil gives some suggestions to Meltem to solve her problems. Tansel is Idil's husband is a successful gourmet. Although, Tansel and Haluk are not good friends, their wives arrange the occasions to make them meet. Hatice and Emine are two relatives and help Idil and Meltem with house chores in Çocuklar Duymasın. In addition, Hüseyin is Emine's husband whereas Şükrü is Hatice's husband. Both of them are lazy characters. There is also a character called Gönül who is Meltem's closest friend. She is also Tuna's wife. She has a son called Orçun from her first marriage. Orçun has a nickname called Beton (Cement). It is nickname indicates that he is a strong character. His role model is Haluk who is his fathers' friend and is a macho man. Orçun's parents display opposite characters. In other words, Gönül is a very dominant and strong woman whereas Tuna is a very passive husband who obeys the rules of his wife. Both of them love Idil and Tansel when they meet.

In all episodes of Çocuklar Duymasın broadcasted on Fox TV in 2014, there is an interesting character called Adem who is an intellectual philosopher. He mentions the popular idioms in his speeches in order to raise the awareness of Turkish people about popular culture and wellknown people. Moreover, Ismail who is Haluk's boss represents an ordinary Turkish Casanova man. He is always in an attempt to have different girl friends to have love and joy with them. All these important characters represent the stories of different types of families in Istanbul.

\section{Theoretical Framework}

The theoretical framework of the study is based on two different aspects, which are Cultivation Theory and Rhetoric Analysis.

In Cultivation Theory, Gerbner (1998) points out that the television is the main storyteller of our time. Television cultivates or creates a worldview. Television also dominates the 
audience's symbolic environment and supplies false views of what reality is like to audience. In other words, Gerbner (1998) puts forth that the audience considers the world very similar to what they watch on TV because television affects gradually the audience's perception and view. Furthermore, according to Harris and Sanborn (2014), the audience hears the laughter, sound and feels happy throughout the jokes that are included in media products of TV. For Harris and Sanborn (2014), if emotional aspect is not supported, the audience may not understand the content of the jokes truly.

As it has been mentioned earlier, Aristotle has defined "Rhetoric" as the art of persuasion (Freese, 1926). On the basis of the definitions, "According to Aristotle, the effective persuasion is possible with three appeals. The speaker should be able to create logical reasoning with his character and personality and to extrapolate the feelings and emotions of the audience which formulating his speech" (Murthy and Ghosal, 2014). In this study, the rhetoric analysis is applied to a Turkish sitcom called Çocuklar Duymasın, which focuses on the life styles of different families. In this respect, the simple jokes and intellectual jokes which are given as a message to the audience in this serial influence the audience's stimulus through the sound of laughter, variety of sounds and the sound of clapping hands in Çocuklar Duymasin. The present study also examines the influence of rhetorical concerns on the audience because the audience starts laughing at the simple jokes and intellectuel jokes in this sitcom. Although the rhetoric analysis includes the examination of ethos, pathos and logos, this study only focuses on the pathos. In other words, the aim of this study is to show how Birol Güven who is the producer/scenarist of Çocuklar Duymasın uses the voice of laughter following the simple jokes and intellectual jokes to create 'pathos' for enjoyment and awareness. Although there are 160 episodes of Çocuklar Duymasın that are broadcasted in Fox TV between 2013 and 2014, the present study analyzes the last 60 episodes broadcasted in 2014.

\section{Methodology}

The present study is based on quantitative methodology. The jokes in 60 episodes of Çocuklar Duymasın broadcasted in 2014 are analyzed, according to the contents of the jokes provided that they are followed by the sound of the laughter. The jokes are classified as simple jokes and intellectual jokes. 


\section{Analysis and Interpretations}

The messages of Çocuklar Duymasın's episodes between 101 and 160 in 2014 are categorized as simple jokes and intellectual jokes. Simple jokes are jokes created through a play with words and intellectual jokes are jokes created through the events in the story. The frequencies of these jokes are presented in this section of the study

Table 1. shows the numbers of simple jokes and intellectual jokes per episode in Çocuklar Duymasin. When the number of the simple jokes and intellectual jokes are counted, the simple jokes are more than the intellectual messages. There are 2214 simple jokes between 101 and 160 episodes of Çocuklar Duymasın in 2014.

The intellectuel jokes' numbers are 251 between 101 and 160 episodes of Çocuklar Duymasın. The audience interpretes the intellectual jokes in Çocuklar Duymasın according to their social, economical and cultural background, Güven aims to articulate more simple jokes than the intellectuel jokes in order to be understood by every audience in Turkish society.

\section{Table 1}

Number of Simple Jokes and Intellectual Jokes per Episode

$\begin{array}{cccc}\text { Number of Episode } & \text { Simple Jokes } & \text { Intellectual Jokes } & \text { Per Serial } \\ 101 & 25 & 5 & 30 \\ 102 & 17 & 4 & 21 \\ 103 & 27 & 6 & 33 \\ 104 & 24 & 3 & 27 \\ 105 & 26 & 5 & 31 \\ 106 & 30 & 3 & 33 \\ 107 & 11 & 6 & 17 \\ 108 & 19 & 6 & 25 \\ 109 & 23 & 6 & 29 \\ 110 & 23 & 8 & 31 \\ 111 & 27 & 4 & 31 \\ 112 & 26 & 8 & 34 \\ 113 & 27 & 6 & 33 \\ 114 & 27 & 7 & 34\end{array}$


Online Journal of Communication and Media Technologies Volume: 7 - Issue: 4 October - 2017

\begin{tabular}{|c|c|c|c|}
\hline 115 & 34 & 7 & 41 \\
\hline 116 & 29 & 7 & 36 \\
\hline 117 & 31 & 5 & 36 \\
\hline 118 & 31 & 4 & 35 \\
\hline 119 & 39 & 5 & 44 \\
\hline 120 & 32 & 3 & 35 \\
\hline 121 & 36 & 2 & 38 \\
\hline 122 & 40 & 6 & 46 \\
\hline 123 & 36 & 4 & 40 \\
\hline 124 & 38 & 3 & 41 \\
\hline 125 & 28 & 2 & 30 \\
\hline 126 & 42 & 2 & 44 \\
\hline 127 & 43 & 5 & 48 \\
\hline 128 & 39 & 2 & 41 \\
\hline 129 & 41 & 2 & 43 \\
\hline 130 & 41 & 1 & 42 \\
\hline 131 & 35 & 2 & 37 \\
\hline 132 & 34 & 4 & 38 \\
\hline 133 & 49 & 3 & 52 \\
\hline 134 & 48 & 4 & 52 \\
\hline 135 & 49 & 3 & 52 \\
\hline 136 & 40 & 2 & 42 \\
\hline 137 & 36 & 4 & 40 \\
\hline 128 & 44 & 5 & 49 \\
\hline 139 & 42 & 5 & 47 \\
\hline 140 & 47 & 4 & 51 \\
\hline 141 & 47 & 3 & 50 \\
\hline 142 & 49 & 3 & 52 \\
\hline 143 & 41 & 3 & 44 \\
\hline 144 & 51 & 3 & 54 \\
\hline 145 & 47 & 3 & 50 \\
\hline 146 & 51 & 3 & 54 \\
\hline 147 & 55 & 2 & 57 \\
\hline
\end{tabular}




$\begin{array}{lllc}148 & 53 & 5 & 58 \\ 149 & 56 & 3 & 59 \\ 150 & 52 & 4 & 56 \\ 151 & 51 & 3 & 54 \\ 152 & 40 & 5 & 45 \\ 153 & 45 & 4 & 49 \\ 154 & 47 & 2 & 49 \\ 155 & 48 & 5 & 53 \\ 156 & 32 & 4 & 36 \\ 157 & 32 & 2 & 34 \\ 158 & 28 & 5 & 33 \\ 159 & 25 & 3 & 28 \\ 160 & 26 & 5 & 31 \\ \text { Total } & 2214 & 251 & 2465\end{array}$

When the simple jokes are analyzed, 8 themes arise. These are: joy, love, anger, guilt, sympathy, fear, empathy and being patriot for the simple jokes. The simple jokes, which are mostly created through a play with words, are associated with the ordinary and normal comic events, jokes and laughter. These jokes are given through messages when the characters give the messages to the audience directly in the serial. Table 2 demonstrates the number of themes for the simple jokes in Çocuklar Duymasın. In total, 2214 themes are classified as the content of the intellectual jokes. When the frequencies of the themes are analyzed, it is seen that the greatest frequency belongs to joy (fun, entertainment). There are 1318 simple jokes including joy. Through the use of joy as a theme, the scenarist and producer of Çocuklar Duymasin not only entertains them but also raises their awareness about important issues. Güven generally aims to articulate the importance of family, marriage and sincere relations in society. Thus, love is also categorized as a theme for the content of the simple jokes. The number of anger as a theme in the simple jokes is 273 . This theme is included to show the ways of coping with a problem for the audience. As it can be seen in Table 2, there are also interesting themes such as guilt, sympathy, fear and empathy in the content of the simple jokes. The lowest frequency, which is 5 belongs to the theme called being a patriot in the simple jokes. 


\section{Table 2}

Themes in Simple Jokes

$\begin{array}{lc}\text { Themes } & \text { Frequency } \\ \text { Fun } & 1318 \\ \text { Love } & 323 \\ \text { Anger } & 273 \\ \text { Guilt } & 147 \\ \text { Sympathy } & 80 \\ \text { Fear } & 58 \\ \text { Empathy } & 10 \\ \text { Being Patriot } & 5 \\ \text { Total } & 2214\end{array}$

The first theme is specified as joy in Çocuklar Duymasın. Joy is a feeling of pleasure and happiness. Thus, some of the simple jokes are given to the audience through the use of joy. For example, through the lips of Tayyar, the scenarist of the serial represents features of the traditional Turkish culture. The information which addresses the audience generally includes jokes of Tayyar. For example, in episode 118, Tayyar states that he is the first person who uses newspapers for cleaning the windows. Another example of joy is expressed by Emine in episode 119. Emine who helps Meltem at home, states that her husband- Hüseyin and her cousin's husband Şükrü are sometimes silly and immature like little children. When she talks about them, she makes fun of their capabilities, behaviors and conversations in order to convince Meltem. Thus, Emine talks about the ways of educating these men. The funny messages are given with a sound and laughter coming from the backstage. Therefore, the simple jokes including joy as a theme are influential in Çocuklar Duymasın.

The second theme is called love. This theme is observed in the content of the simple jokes in Çocuklar Duymasın because love is seen as a strong feeling of affection in some of the messages that leads to laughter and appreciation. In episode 122, Tuna encourages Haluk to organize a special day for the anniversary of Meltem and Haluk. Tuna is a character who always talks about the importance of love in Çocuklar Duymasın. During the conversation between these two characters, Haluk who is a macho man doesn't want to celebrate this special event because he holds that a macho man doesn't prefer to organize a special event 
for the anniversary. Haluk's rejection leads to a comic explanations and situations. Thus, the audience laugh at them while they are listening to Haluk and Tuna who are opposite characters in Çocuklar Duymasın. When the messages about love are given in an interesting way, a romantic sound comes from the backstage. Through the use of this sound, Pathos is created for love.

The third theme in the simple jokes is called anger. This theme is generally observed in a strong feeling of annoyance, displeasure and hostility in Çocuklar Duymasın. For example, in episode 133, Meltem gets angry with Haluk while he is eating meat because she is a vegetarian. Meltem's attitude towards Haluk is very aggressive due to the displeasure. This fact is presented as a comedy through the use of background sounds.

The fourth theme in the simple jokes is called guilt. The scenarist employs guilt as a theme because it refers to the fact of having committed an offence or crime, which adversely affects people's sphere of lives. For example, while Teo, Havuç, Ece and Melis are spending time together in a cafe, there is a boy who harasses girls in episode 140. Although young boys get nervous, they prefer to warn this man instead of acting violently. The conversation among the characters is interesting and is supported by the sound and laughter coming from the background. This example demonstrates that the guilt can be a theme that is included in the content of the simple joke.

Sympathy is also a theme that is included in the simple jokes. For example, it is replaced in the $151^{\text {th }}$ episode. Through the character of Tansel, the scenarist of Çocuklar Duymasın attempts to articulate the importance of art and artists in this century. For example, the barely educated men who are Şükrü and Hüseyin are in an attempt to make money when they draw paintings and sell them. They want to be rich at the end of these sales. When they talk about this issue with Tansel, he appreciates the strive of Şükrü and Hüseyin, for drawing a picture even though they are not professionals. The conversation among these characters is very funny because Şükrü and Hüseyin are not talented for painting. This fact creates a common feeling for the understanding of art while giving the simple jokes to the audience. Idil gives the second example of this theme in the $111^{\text {th }}$ episode. While Tansel and Idil are talking to each other, Idil points out that Hatice who helps Idil at home, should share the same table with them in the dining room even though Hatice is slightly an eccentric and funny woman. 
This fact causes laughter and amusement while the audience is watching the conversation of these characters. However, this comic situation not only makes the audience laugh but also raises their awareness of humanity and kindness in case of the relationship between a patron and a servant.

The sixth theme in the simple jokes is called fear. This theme refers to an unpleasant emotion, which is caused by the threat of danger, pain or harm. For example, in episode 120, when Hatice's husband Hüseyin demands money from Hüseyin, she gives her salary to him. Hatice always obeys what she is told because she is afraid of him. This emotion is shown to the audience through the facial expressions and words told by Emine in Çocuklar Duymasın. While Emine's expressions entertain the audience, this emotion is also imposed on the audience.

Empathy is also a prominent theme. It is categorized under the content of the simple jokes. Empathy is associated with the ability to understand and share the feelings of another. Therefore, the simple jokes, which are based on empathy, are included in Çocuklar Duymasin. The aim of the scenarist is to bring an important feeling, memory or image to the conscious mind of the audience. For example, in episode 143, Meltem who is the mother of Duygu and Havuç defends that the parents should put themselves in their children's shoes while their children are making decision about marriage, occupation, education, etc. In the conversation, Haluk, who is the father of these young people, agrees with Meltem. While the characters are giving this important message to the audience, the sound of clapping comes from the background.

There is also an example for the empathy, which is declared by Meltem in episode 119. Meltem articulates that people shouldn't put their mobile phones in their bedrooms to be healthy when they go to sleep. She states that the medical doctors in the international conference announce this fact. This message given by the scenarist also raises the awareness of the audience about an important issue. The eighth theme is called being a patriot. The scenarist includes this theme in the content of the simple jokes because of the Turkish men's vigorous support of their country. In episode 113, Teo asserts that every man should perform his military service in order to defend the country successfully against enemies. In addition, Haluk talks about jeered, which is a traditional support of his ancestors in the $117^{\text {th }}$ episode. 
While these simple jokes are given to the audience, there is a sound of laughter. In this respect, the audience is expected to laugh at these jokes when they hear this sound.

When the themes in the intellectual jokes are analyzed, there are ultimately 6 themes: joy, love, sympathy, guilt, anger and empathy for the intellectual jokes in this serial. The intellectual jokes include hidden meanings. Therefore, the intellectual jokes give implicit messages to the audience. The intellectual jokes, which include jokes and laughter, affect the audience's decision mechanism and interpretations. In other words, the scenarist and producer Güven makes the audience evaluate their lives through the simple jokes and intellectual jokes in the serial. Table 3 below is used to show the number of themes that are included in the intellectual jokes for the audience of Çocuklar Duymasın. In total, 251 themes are stated in the content of the intellectual jokes. When the frequencies of the themes are analyzed, it is seen that the greater frequencies belong to joy and love. There are 87 intellectual jokes including joy whereas there are 83 intellectual jokes including love in their contents, respectively. The lowest frequency belongs to the theme called empathy in the intellectual jokes.

\section{Table 3}

The Number of The Themes in Intellectual Jokes

$\begin{array}{lc}\text { Themes } & \text { Frequency } \\ \text { Joy } & 87 \\ \text { Love } & 83 \\ \text { Sympathy } & 29 \\ \text { Guilt } & 21 \\ \text { Anger } & 20 \\ \text { Empathy } & 11 \\ \text { Total } & 251\end{array}$

Furthermore, the first theme, which is called joy, is associated with a feeling of great pleasure and happiness in the content of the intellectual joke. The number of the joy is 87 out of 251 themes. For example, in episode 117, Tansel states that there is a variety of cuisines in the world. In his speech, he introduces different styles and methods of cooking to Haluk. Since Haluk is a traditional man, he does not accept Tansel's explanations. For example, Tansel 
contends that bourgeois families prefer to eat a fin of shark and Beijing duck. When Haluk hears these interesting preferences, he starts to make fun of Tansel. Throughout the conversation between these characters, there exists a sound of laughter coming from the background. This intellectual joke asserts the importance of being open to new concerns.

The second theme is specified as love in the intellectual messages. The number of this theme is 83. For example, in episode 111, there is a conversation about love between Haluk and Meltem. When Meltem wants Haluk to show how much he loves her, Haluk states that the real man always makes his wife feel the real love. Thus, there is not a special need to show such a feeling to a woman for Haluk. While the characters are talking to each other, there is a sound of clapping the hands to appreciate Haluk's expression. When the conversation is completed, Haluk's message is implicitly given to the audience. The intellectual jokes generally raise the awareness of the audience about important issues in Çocuklar Duymasın. In this respect, this message, which is based on love, also influences the knowledge or perception of love for the audience.

In addition, sympathy is the third theme, which is given to the audience in the content of Çocuklar Duymasın's intellectual jokes. There are 29 intellectual jokes which include sympathy as a theme in theory contents. Sympathy represents support in the form of shared feelings or opinions. Thus, when the audience feels the common feeling that the character expresses, they are automatically influenced by formal expressions of distinct feelings. For example, Haluk articulates that he is very happy when his son has started to walk at the age of 3 in episode 119. This expression creates a respect and warm approval of forming a family in society. In other words, the scenarist and producer of Çocuklar Duymasın uses Haluk's explanations to demonstrate the importance of family which is regarded impressive and worthy of admiration.

The fourth theme is called guilt that is observed in the intellectual jokes of Çocuklar Duymasin. The frequency of guilt is 21 in the intellectual jokes. For example, in episode 114, Meltem insists on encouraging Haluk to learn a foreign language. Haluk doesn't agree with his wife. Then, Meltem never gives up and asserts, "each new language means a new experience and life-style". Throughout the conversation, for Meltem, Haluk is guilty to be 
reluctant and stubborn. This intellectual joke articulates the importance of learning a foreign language implicitly.

The fifth theme is called anger. The number of the anger as a theme in the intellectual jokes is 20. This theme refers to a strong feeling of annoyance, displeasure or hostility in the content of the intellectual joke. Through the use of anger as a theme in Çocuklar Duymasin, the scenarist and producer Güven aims to raise the awareness of the audience about incorrect consumption. For example, in episode 136, there is a conversation between Meltem and Haluk. Haluk warns Meltem to be a rational consumer. In other words, for Haluk, there is no need to consume for being a beautiful woman. He criticizes Meltem's shopping for cosmetics, skin care, fashion garments, etc. The sound of laughter also takes place during this conversation. Thus, it is hoped that the audience is enjoying the media while they are evaluating Haluk's message.

The last theme is called 'empathy' which is given as a theme in the intellectual jokes. The number of the empathy as a theme in the intellectual jokes is 11 . This theme is used to give intellectual joke about the ability to understand and share the feeling of another in the content of the intellectual jokes. For example, in episode 151, there is a conversation between Tuna and Gönül. Tuna's wife who is Gönül declares that a person shouldn't ask a question if they know and predict the answer of that question. According to Gönül, there is no need to hear the answers openly. Instead of asking questions to learn the answers, individuals should put themselves in others' shoes. Tuna is very funny and helps Gönül set her argument effectively for the audience. Thus, this message is an intellectual joke, which is observed in Çocuklar Duymasın, too. Çocuklar Duymasın adresses to a wide variety of audience. Among these, social messages meant for everyone. These jokes are mostly done through the play of words. Everyone, including children, understand them. Yet, intellectuel jokes, are meant for rather intellectuel people. These jokes require craft on the side of the producer. They are created through the elements of the story. The sound of laughter follows both social messages and intellectuel messages. With this respect, it acts as a stimules to raise the audience's consciousness that a joke has passed by. Thus, the producer seeks to create pathos. 


\section{Conclusion}

This study shows how the producer and the scenarist of Çocuklar Duymasın, Güven uses both the simple jokes and the intellectual jokes in this sitcom. In this respect, the theoretical framework of the study is based on not only the Cultivation Theory but also on the Rhetoric Analysis. According to the Cultivation Theory by Gerbner (1998), the study shows that Güven would like to cultivate the audience through the use of simple and intellectual jokes expressed by the characters in the serial. He also aims to influence the audience's stimulus for jokes with the sound of laughter. The pathos in rhetoric analysis takes place in this serial to give important messages to the audience. Therefore, the producer and the scenarist of this sitcom is in an attempt to give the simple jokes and intellectual jokes under the categorization of certain themes. The present study sought to explore the jokes put forth in the serial and to categorize them as simple or intellectual jokes.

The data collection method of the study is based on content analysis which is conducted through the use of a checklist. Two researchers watched and recorded data on the coding sheet to ensure inter-rater reliability. The emerging themes are determined as joy, love, empathy, sympathy, fear, anger, guilt and being patriot for the simple jokes and love, joy, guilt, sympathy, anger and empathy for the intellectual jokes in this study.

The results confirm that the number of the simple jokes between the episodes 101 and 160 is 2214 whereas the number of the intellectual jokes is 251 in these episodes of this sitcom (See Table.1). The number of the simple jokes is more than the number of the intellectual jokes because the aim of Güven is not only to entertain the audience but also to raise their awareness to important issues no matter which social class they belong to. In addition, the intellectual jokes necessitate a greater deal of creativity in order to craft the content of the jokes. They address to rather more educated audience than everyone. These jokes sometimes cannot be fully understood by the entire audience. Therefore, Güven includes simple jokes more than the intellectual jokes.

In addition, when the number of the themes for the simple jokes are analyzed, it is seen that 1318 simple jokes classified are classified as joy, 323 simple jokes are classified as love, 273 simple jokes are classified as anger, 147 simple jokes are classified as guilt, 80 simple jokes are classified as empathy, 58 simple jokes are classified as fear and 10 simple jokes classified 
as empathy and 5 simple jokes are classified as being patriot (See Table 2). On the other hand, when the number of the themes in the intellectual jokes are examined, it is seen that there are 87 intellectual jokes, that are classified as joy, 83 intellectual jokes that are classified as love, 29 intellectual jokes that are classified symapthy, 21 intellectual jokes are classified as guilt, 20 intellectual jokes that are classified as anger and 11 intellectual jokes that are classified as empathy as a theme in their contents (See Table. 3). While creating these jokes, the aim is not only to provide enjoyment for the audience but also to raise their awareness about important issues. While doing these, the producer uses the sound of laughter in order to create pathos with laughter and sounds.

In conclusion, Çocuklar Duymasın is one of the most popular Turkish TV sitcoms of all times employs different strategies to entertain the audience. One of these strategies is to use the sound of laughter in order to create pathos. This device has been widely used in this serial in order to create stimulus for fun. The use of sound of laughter has been a common strategy used by the producers to signal a joke. By employing this strategy, Güven shows preference to use a universal device. 


\section{References}

Berger, A. A. (2011). Media and Communication Research Methods. London: Sage. Facebook.com/CocuklarDuymasin.

Freese, J.H. (1926). The Art of Rhetoric by John Henry Freese. London: William Heinemann.

Gerbner, G. (1998). Cultivation Analysis: An Overview. Mass Communication and Society, 3(4), 175-194.

Harris, R.J. \& Sanborn W.F. (2014). A Cognitive Psychology of Mass Communication. London: Routledge.

Murthy, L.D.M \& Ghosal, M,. (2014). A Study on Aristotle's Rhetoric. Research Journal of English Language and Literature. 2 (4), 249-255.

Rapp, C. (2010). "Aristotle's Rhetoric", The Stanford Encyclopedia of Philosophy (Spring 2010 Edition), Edward N. Zalta (ed.).

Tom, G \& Eves, A. (1999). The Use of Rhetorical Devices in Advertising. Journal of Advertising Research. 1 (5), 39-43. 